\title{
Improvement in Quality of Care for Patients with Type 2 Diabetes in Hungary Between 2008 and 2016: Results from Two Population-Based Representative Surveys
}

\author{
Attila Nagy • Nóra Kovács · Anita Pálinkás · Valéria Sipos · \\ Ferenc Vincze · Gergő Szőllősi · Róza Ádány · Árpád Czifra · \\ János Sándor
}

Received: November 27, 2018 / Published online: February 15, 2019

(C) The Author(s) 2019

\section{ABSTRACT}

Introduction: Due to the increasing trends of recent decades, diabetes prevalence has reached a frequency of $1 / 11$ adults worldwide. However, this disadvantageous trend has not been accompanied by worsened outcome indicators; better short-term (e.g., HbA1c levels) and longterm [e.g., all-cause mortality among type 2 diabetes mellitus (T2DM) patients] outcomes can be observed globally. We aimed to describe changes in the effectiveness of type 2 diabetes mellitus care between 2008 and 2016 based on outcome indicators.

Enhanced Digital Features To view enhanced digital features for this article go to: https://doi.org/10.6084/ m9.figshare.7667249.

A. Nagy · N. Kovács · A. Pálinkás · V. Sipos ·

F. Vincze · G. Szőllősi · J. Sándor ( $₫)$

Department of Preventive Medicine, Faculty of Public Health, University of Debrecen, Debrecen, Hungary

e-mail: sandor.janos@sph.unideb.hu

R. Ádány

MTA-DE Public Health Research Group of the Hungarian Academy of Sciences, Department of Preventive Medicine, Faculty of Public Health, University of Debrecen, Debrecen, Hungary

\section{Á. Czifra}

General Practitioners' Cluster Haláp, Department of Preventive Medicine, Faculty of Public Health, University of Debrecen, Debrecen, Hungary
Methods: The study is a secondary analysis of data from two previously performed surveys. Both surveys were conducted in the framework of the General Practitioners' Morbidity Sentinel Stations Program (GPMSSP), which maintains a nationally representative registry of T2DM patients.

Results: The largest improvement was observed in achieving fasting blood glucose and HbA1c target values $[\mathrm{OR}=0.67,95 \%$ confidence interval $(\mathrm{CI}), 0.56-0.80$ and $\mathrm{OR}=0.58 ; 95 \% \mathrm{CI}$, $0.48-0.70$, respectively]. Moderate improvement was detected by reaching body mass index (BMI), diastolic blood pressure and total cholesterol target values $(\mathrm{OR}=0.78,95 \% \mathrm{CI}$, $0.65-0.93 ; \mathrm{OR}=0.78,95 \% \mathrm{CI}, 0.65-0.94$ and $\mathrm{OR}=0.76,95 \% \mathrm{CI}, 0.63-0.92$, respectively).

Conclusion: Our study demonstrated that if standardized indicators are investigated in population-based samples, the effectiveness of T2DM care can be monitored by ad hoc surveys. The systematic application of this approach completed with the detailed documentation of the applied therapies could demonstrate the public health impact of certain modifications in T2DM care. An overall improvement in metabolic control (glycaemic control, lipid status and obesity) was observed, which was not accompanied by improved therapeutic target achievement for systolic blood pressure.

Keywords: Care quality; Outcome indicators; Type 2 diabetes mellitus; Surveys 


\section{INTRODUCTION}

According to the International Diabetes Federation's latest estimations, diabetes prevalence has reached a frequency of $1 / 11$ adults worldwide in accordance with the increasing trends of recent decades. However, this disadvantageous trend has not been accompanied by worsened outcome indicators; better short-term (e.g., HbA1c levels) and long-term [e.g., allcause mortality among type 2 diabetes mellitus (T2DM) patients] outcomes can be observed globally [1]. It is widely accepted that improvements in glycaemic control and prognosis can be attributed to the considerable extension of therapeutic means (introduction of new OADs, insulin formulations and personalized treatment) [2-6]. Nevertheless, substantive analysis of the public health impact of improved care is lacking.

According to the series of Hungarian national guidelines released between 2008 and 2016, the assortment of therapeutics used in Hungary has increased as well. The first evidence-based guideline was published in 2009. Contrary to prior recommendations with strict cut-off values, the recent guidelines specify personalized target ranges. The Diabetes License Certificate was established in 2012. There were dynamic changes in the utilisation of therapeutic methods, such as DPP-4 inhibitors, GLP1 agonists and newly developed insulin analogues. The first agent of the DPP-4 inhibitor class was sitagliptin, which was introduced in 2009. Given its stable postprandial glycaemic control and decent side effect profile, its usage has increased during the subsequent years. More molecules have appeared, and the production of fixed combination therapy with metformin was initiated. GLP-1 agonists exhibit improved glycaemic control with stable body weight reduction effects, but the relatively higher price and subcutaneous method of administration make it less preferable than other therapies; this agonist is mostly prescribed to patients with a good clinical status. SGLT2 inhibitors were introduced in 2014. Moreover, the introduction of insulin analogues also had a major impact on glycaemic control. These new types of insulin also have a favourable effect on body weight compared with regular insulin [7-13]. Similar guidelines are found in the surrounding region (e.g., in Slovakia and Romania) $[14,15]$.

However, in Hungary, GPs diagnose and regularly care for these patients (including metabolic control), but antidiabetic drugs (especially the newly introduced ones) are generally prescribed by specialists [16].

The public health impact of this progress has not yet been investigated in Hungary, as the country could not participate in recent European surveys on the quality of diabetes care $[17,18]$.

The objective of our investigation was to describe the change in the quality of T2DM care in Hungary with respect to key outcome indicators in the period of therapy improvement between 2008 and 2016.

\section{METHODS}

\section{Data Collection}

The study is a secondary analysis of data from two previously performed surveys. Both surveys were conducted in the framework of the General Practitioners' Morbidity Sentinel Stations Program (GPMSSP), which maintains a nationally representative registry of T2DM patients [19]. This registry provided the sampling frame for both surveys.

Data collection for the first survey was performed in 2008. The first study mainly focused on comorbidities and complications; therefore, the investigated sample was selected from and representative of Hungarian T2DM patients $>$ 50 years old $(N=1324)$. After excluding nonrespondents and patients with incomplete records, the sample size was 1039. Case report forms were completed by GPs, and the forms recorded the socio-demographic data of patients, duration of T2DM (DoD), manifestation of complications and comorbidities, information on control examinations and effectiveness of care. Details of data collection were described elsewhere [20-22]. 
The second population-based cross-sectional $(N=1280)$ study was performed in 2016 to create a nationally representative sample of adult T2DM patients in the framework of GPMSSP. The sample consisted of 1089 patients after excluding those with incomplete data and those $<50$ years old. The same type of data was collected as described in the 2008 survey according to the published study design [22].

\section{Statistical Analysis}

Data sets from 2008 and 2016 surveys were merged because the variables and methodology used to collect data for variables were identical. Percentages of uncontrolled patients (not achieving target values) were calculated for key outcome indicators. The difference between the proportions from 2008 and 2016 were calculated. Therapeutic target values were defined according to the National Guideline of the Hungarian Diabetes Association [10]. Sample compositions were described separately and compared with the chi-squared test and Student's $t$-test.

Multivariate logistic regression models were created to assess the effect of change (2008-2016) on the following indicators: fasting blood glucose $(\geq 7.8 \mathrm{mmol} / \mathrm{l})$; HbA1c $(\geq 7 \%)$; body mass index (BMI) $\left(<30 \mathrm{~kg} / \mathrm{m}^{2}\right)$; waist circumference $(\geq 102 \mathrm{~cm}$ for males; $\geq 88 \mathrm{~cm}$ for females); systolic blood pressure $(\geq 140 \mathrm{mmHg}$ ); diastolic blood pressure ( $\geq 85 \mathrm{mmHg}$ ); blood pressure (systolic blood pressure $\geq 140 \mathrm{mmHg}$ and diastolic blood pressure $\geq 85 \mathrm{mmHg}$ ); and total cholesterol $(\mathrm{TC} ; \geq 4.5 \mathrm{mmol} / \mathrm{l})$. The availability rate of each lipid parameter was $98.56 \%(1024 / 1039)$ in 2008. The availability rate was $90.82 \%$ (989/ $1089)$ for TC, $57.39 \%(625 / 1089)$ for LDL-C and 75.94\% (827/1089) for HDL-C in 2016. LDL-C and HDL-C were not analysed given the relatively high proportion of missing data. The controlled confounding factors were age, gender, DoD and level of education (classified as primary, secondary and tertiary). Adjusted odds ratios (OR) with the corresponding 95\% confidence intervals $(95 \% \mathrm{CI})$ were used to describe the dependency of outcome indicators based on the year of data collection.

\section{Compliance with Ethics Guidelines}

Ethical approval for the secondary analysis was not required. The original surveys were approved by Ethics Committee of the University of Debrecen (2699-2007) and the Hungarian National Scientific Council on Health (TUKEB 48495-2/2014/EKU). Informed consent was obtained from all individual participants included in the study.

\section{RESULTS}

The main patient characteristics are provided in Table 1. Significant improvements in several outcome indicators were noted in the studied period (Table 2). The biggest improvement was observed in achieving fasting blood glucose and HbA1c target values $(\mathrm{OR}=0.67,95 \% \mathrm{CI}$, $0.56-0.80$ and $\mathrm{OR}=0.58 ; 95 \% \mathrm{CI}, 0.48-0.70$, respectively). Moderate improvement was detected by reaching BMI, diastolic blood pressure and total cholesterol target values $(\mathrm{OR}=$ 0.78, 95\% CI, 0.65-0.93; OR = 0.78, 95\% CI, $0.65-0.94$ and $\mathrm{OR}=0.76,95 \% \mathrm{CI}, 0.63-0.92$, respectively). Although small, significant improvement was observed in waist circumference $(\mathrm{OR}=0.71,95 \% \mathrm{CI}, 0.56-0.89)$. However, slight but non-significant improvements were noted for systolic blood pressure $(\mathrm{OR}=0.92$, 95\% CI, 0.77-1.09) and systolic/diastolic blood pressure $(\mathrm{OR}=0.88,95 \% \mathrm{CI}, 0.74-1.06)$.

\section{DISCUSSION}

According to our investigation, the average age and DoD among the $>50$-year-old Hungarian T2DM patients shifted upwards from 2008 to 2016. Because the studied subjects, of which there were $>1000$, were representative of $>$ 50-year-old Hungarian T2DM patients selected by the same process with data collection organised in the same manner, the comparison is not biased. The observed trends are specific to 
Table 1 Patient characteristics in the studied samples representative of Hungarians with type 2 diabetes $\geq 50$ years old

\begin{tabular}{lllr}
\hline Patient characteristics & $\mathbf{2 0 0 8}(\boldsymbol{N}=\mathbf{1 0 3 9})$ & $\mathbf{2 0 1 6}(\boldsymbol{N}=\mathbf{1 0 8 9})$ & $\boldsymbol{p}$ value \\
\hline Gender (female/male proportions) & $51.01 \% / 48.99 \%$ & $55.83 \% / 44.17 \%$ & $0.026^{\mathrm{a}}$ \\
Age (mean \pm SD, years) & $66.48 \pm 9.18$ & $68.42 \pm 9.09$ & $<0.001^{\mathrm{b}}$ \\
Primary education & $43.31 \%$, & $40.59 \%$ & $0.014^{\mathrm{a}}$ \\
Secondary education & $47.83 \%$ & $46.65 \%$ & \\
Tertiary education & $8.76 \%$ & $12.76 \%$ & \\
Duration of diabetes (mean \pm SD, years) & $8.87 \pm 6.18$ & $10.15 \pm 6.73$ & $<0.001^{\mathrm{b}}$ \\
Controlled HbAlc & $45.40 \%(n=464)$ & $56.93 \% \%(n=546)$ & $<0.001^{\mathrm{a}}$ \\
Controlled fasting blood glucose & $45.02 \%$ & $55.08 \%$ & $<0.001^{\mathrm{a}}$
\end{tabular}

a Chi-square test

b Student $t$-test

Table 2 Proportion of patients with type 2 diabetes $>50$ years od in Hungary that did not achieve therapeutic targets in 2008 and 2016

\begin{tabular}{|c|c|c|c|c|}
\hline $\begin{array}{l}\text { Investigated outcomes } \\
\left(\mathbf{N}_{2008} / \mathbf{N}_{2016}\right)\end{array}$ & $\begin{array}{l}\text { Proportion of } \\
\text { uncontrolled in } 2008 \\
(N=1039)\end{array}$ & $\begin{array}{l}\text { Proportion of } \\
\text { uncontrolled in } 2016 \\
(N=1089)\end{array}$ & $\begin{array}{l}\text { Difference }^{a} \text { between } \\
\text { proportions of } \\
\text { uncontrolled }\end{array}$ & $\begin{array}{l}\text { Adjusted OR } \\
{\left[\begin{array}{ll}95 \% & \mathrm{CI}\end{array}\right]^{\mathrm{b}}}\end{array}$ \\
\hline $\begin{array}{l}\text { Fasting blood glucose } \\
\qquad(1024 / 1044)\end{array}$ & $54.98 \%(n=563)$ & $44.92 \%(n=469)$ & $-10.06 \%$ & $0.67[0.56-0.80]$ \\
\hline HbAlc $(1022 / 959)$ & $54.60 \%(n=558)$ & $43.07 \%(n=413)$ & $-11.53 \%$ & $0.58[0.48-0.70]$ \\
\hline BMI (1037/1089) & $59.40 \%(n=616)$ & $51.70 \%(n=563)$ & $-7.70 \%$ & $0.78[0.65-0.93]$ \\
\hline $\begin{array}{l}\text { Waist circumference } \\
\qquad(1034 / 1089)\end{array}$ & $82.40 \%(n=852)$ & $78.15 \%(n=851)$ & $-4.25 \%$ & $0.71[0.56-0.89]$ \\
\hline $\begin{array}{l}\text { Systolic blood pressure } \\
(1027 / 1089)\end{array}$ & $49.66 \%(n=510)$ & $47.11 \%(n=513)$ & $-2.55 \%$ & $0.92[0.77-1.09]$ \\
\hline $\begin{array}{l}\text { Diastolic blood pressure } \\
\quad(1027 / 1089)\end{array}$ & $35.83 \%(n=368)$ & $29.57 \%(n=322)$ & $-6.26 \%$ & $0.78[0.65-0.94]$ \\
\hline $\begin{array}{l}\text { Systolic and diastolic } \\
\text { blood pressure }(1027 / \\
1089)\end{array}$ & $57.94 \%(n=595)$ & $54.55 \%(n=594)$ & $-3.39 \%$ & $0.88[0.74-1.06]$ \\
\hline $\begin{array}{l}\text { Total cholesterol (1024/ } \\
\text { 989) }\end{array}$ & $68.95 \%(n=706)$ & $62.89 \%(n=622)$ & $-6.06 \%$ & $0.76[0.63-0.92]$ \\
\hline
\end{tabular}

${ }^{\text {a }}$ Proportion of uncontrolled in 2008 subtracted from proportion of uncontrolled in 2016

b Odds ratio adjusted for age, gender, level of education and duration of diabetes with corresponding $95 \%$ confidence interval; reference year 2008 
Hungary and have not been described previously.

Given that the prevalence of T2DM was not changed in this study period according to the Hungarian implementation of European Health Interview Surveys $(8.43 \%$ in $2009 ; 8.17 \%$ in $2014 ; p=0.605)$ and given the unfortunate lack of organized screening and effective primary preventive programmes in Hungary [23, 24], the change can be attributed to the increase in Hungarian T2DM patients' life expectancy from 2008 to 2016, primarily among more educated women.

Age, gender, education and DoD-adjusted care quality outcome indicators revealed that control of glycaemic status, obesity, lipid status and diastolic blood pressure improved significantly between 2008 and 2016, whereas the therapeutic target achievement for systolic blood pressure showed no similar trend.

Care of the T2DM patients with hypertension is still mostly managed by their GPs. Given the lack of therapeutic experience or not knowing the stricter blood pressure targets, many of these patients are undertreated. It is also important to note that the fear of conditions caused by hypotensive episodes occasionally leads GPs to administer inadequate dosages or insufficient combinations of antihypertensive drugs.

This pattern of change can be attributed to sharing of tasks in care. Blood pressure is considered controlled by GPs. Diabetologists in outpatient secondary centres are responsible for patients' metabolic status. This task sharing is determined by the difference in the drug prescription opportunities of general practitioners and specialists.

Although age restriction prevents a simple comparison of our observations with published international reference data and the key indicator of LDL-C concentration was replaced by the TC level in our investigation, our results seem to be similar to the range of indicator values published in European countries [17, 18].

Although the total number of patients was only a little more than 1000 in both studies, the sample sizes still provided enough statistical power for our investigated indicators. Actually, the main limitation of our analysis was that the indicator set contained only few-although the most important-indicators. The long-term outcome indicators were missing as we did not have data for them [25].

The drug-specific health gains could not be investigated in our analysis because patientlevel medication data were not available. Consequently, this demonstration of improved effectiveness of T2DM care does not prove the causal association between care quality improvement and improved life expectancy. Taking into consideration the known efficiency of new therapeutic methods, these results suggest that the introduction of new methods into the therapeutic regimes ultimately contributes to a better prognosis.

\section{CONCLUSION}

Our study demonstrated that if standardised indicators [25] are investigated in populationbased samples, the effectiveness of T2DM care can be monitored by ad hoc surveys. The systematic application of this approach completed with the detailed documentation of applied therapies could demonstrate the public health impact of certain modifications in T2DM care, which could contribute to a better understanding of the added value of new therapies proven to be efficient in clinical trials at the public health level.

\section{ACKNOWLEDGEMENTS}

We thank the participants of the study.

Funding. The reported studies were performed in the framework of the "Public Health Focused Model Programme for Organizing Primary Care Services Backed by a Virtual Care Service Centre" (SH/8/1). Additional funding was provided by a grant from the Hungarian Academy of Sciences (MTA 11003, 2006TKI227); the IGEN-HUNGARIAN (TÁMOP4.2.2.AA-11/1/KONV-2012-0031) project, which was co-financed by the European Union and the European Social Fund; and the GINOP- 
2.3.2-15-2016-00005 project, which was co-financed by the European Union and the European Regional Development Fund. The article processing charges were funded by the authors.

Authorship. All named authors meet the International Committee of Medical Journal Editors (ICMJE) criteria for authorship for this article, take responsibility for the integrity of the work as a whole, and have given their approval for this version to be published.

Disclosures. Attila Nagy, Nóra Kovács, Anita Pálinkás, Valéria Sipos, Ferenc Vincze, Gergő Szőllősi, Róza Ádány, Árpád Czifra and János Sándor have nothing to disclose.

Compliance with Ethics Guidelines. Ethical approval for the secondary analysis was not required. The original surveys were approved by Ethics Committee of the University of Debrecen (2699-2007) and the Hungarian National Scientific Council on Health (TUKEB 48495-2/ 2014/EKU). Informed consent was obtained from all individual participants included in the study.

Data Availability. The data sets generated during and/or analysed in the current study are not publicly available for further analyses but are available from the corresponding author on reasonable request.

Open Access. This article is distributed under the terms of the Creative Commons Attribution-NonCommercial 4.0 International License (http://creativecommons.org/licenses/ by-nc/4.0/), which permits any noncommercial use, distribution, and reproduction in any medium, provided you give appropriate credit to the original author(s) and the source, provide a link to the Creative Commons license, and indicate if changes were made.

\section{REFERENCES}

1. IDF Diabetes Atlas, 8th edn. Brussels, Belgium. IDF Diabetes Atlas, 8th edn. [Internet]. 2017 [cited 2018 Oct 13]. http://www.diabetesatlas.org.
2. Abd El, Aziz MS, Kahle M, Meier JJ, Nauck MA. A meta-analysis comparing clinical effects of short- or long-acting GLP-1 receptor agonists versus insulin treatment from head-to-head studies in type 2 diabetic patients. Diabetes Obes Metab. 2017;19:216-27.

3. Herrero Gil AM, Pinillos Robles J, Sabio Repiso P, Martín Maldonado JL, Garzón González G. Gil de Miguel Á [Trends in the level of control of patients with type 2 diabetes from 2010 to 2015]. Aten Primaria. 2018;50:459-66.

4. Luo M, Tan KHX, Tan CS, Lim WY, Tai E-S, Venkataraman K. Longitudinal trends in HbA1c patterns and association with outcomes: a systematic review. Diabetes Metab Res Rev. 2018;34:e3015.

5. Menke A, Casagrande S, Geiss L, Cowie CC. Prevalence of and trends in diabetes among adults in the United States, 1988-2012. JAMA. 2015;314:1021-9.

6. Yang Y, Chen S, Pan H, Zou Y, Wang B, Wang G, et al. Safety and efficiency of SGLT2 inhibitor combining with insulin in subjects with diabetes: systematic review and meta-analysis of randomized controlled trials. Medicine (Baltimore). 2017;96:e6944.

7. National guideline for diabetes care of Hungarian Diabetes Association [Internet]. 2005 [cited 2018 Oct 13]. http://ftsz.pte.hu/docs/protokollok/ BELDiabetes_mellitus_IE.pdf.

8. National guideline for diabetes care of Hungarian Diabetes Association [Internet]. 2009 [cited 2018 Oct 13]. https://old-kollegium.aeek.hu/conf/upload/ oldiranyelvek/BELGY_diabetes\%20mellitus\%20koris mezese-a\%20cukorbetegek\%20kezelese\%20es\%20gon

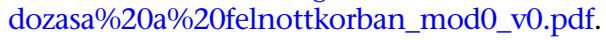

9. National guideline for diabetes care of Hungarian Diabetes Association [Internet]. 2011 [cited 2018 Oct 13]. https://www.doki.net/tarsasag/diabetes/ upload/diabetes/document/MDT_szakmai_iranyelv_ 2011_DH_Suppl_20110419.pdf?web_id=934ef28191 aaefd.

10. National guideline for diabetes care of Hungarian Diabetes Association [Internet]. 2014 [cited 2018 Oct 13]. https://www.doki.net/tarsasag/diabetes/ upload/diabetes/document/dh14s1_szakmaiiranyelv_ 2014.pdf?web_id=934ef28191aaefd.

11. Hungarian Diabetes Association [Internet]. http:// www.diabet.hu/hirek.aspx? \&nid=33641\&cid=241. 2018 [cited 2018 Nov 21]. http://www.diabet.hu/ hirek.aspx?\&nid=33641\&cid=241.

12. Jermendy G, Kiss Z, Rokszin G, Abonyi-Tóth Z, Wittmann I. Kempler P [Trends in antidiabetic treatment prescribed for patients with type 2 
diabetes in Hungary between 2001 and 2014-results from the database analysis of the National Health Insurance Fund]. Orv Hetil. 2017;158:770-8.

13. Jermendy G, Kiss Z, Rokszin G, Abonyi-Tóth Z, Wittmann I, Kempler P. Persistence to treatment with novel antidiabetic Drugs (dipeptidyl peptidase-4 inhibitors, sodium-glucose co-transporter-2 inhibitors, and glucagon-like peptide-1 receptor agonists) in people with type 2 diabetes: a nationwide cohort study. Diabetes Ther Res Treat Educ Diabetes Relat Disord. 2018;9:2133-41.

14. Roman G, Hancu N. Early insulin treatment to prevent cardiovascular disease in prediabetes and overt diabetes. Horm Metab Res Horm Stoffwechselforschung Horm Metab. 2009;41:116-22.

15. Konsenzuálne terapeutické odporúčanie slovenskej diabetologickej spoločnosti pre diabetes mellitus 2 . TYPU (2018) [Internet]. [cited 2019 Jan 6]. http:// www.edukafarm.sk/soubory/sylaby/2018/PodsekciaDiabetesNews/KONSENZUALNE-TERAPEUTICKEODPORUCANIE-SLOVENSKEJ-DIABETOLOGICKEJSPOLOCNOSTI-PRE-DIABETES-MELLITUS-2-TYPU(2018).pdf.

16. Rurik I. Primary care diabetes in Hungary. Prim Care Diabetes. 2007;1:177-9.

17. de Pablos-Velasco P, Parhofer KG, Bradley C, Eschwège E, Gönder-Frederick L, Maheux $\mathrm{P}$, et al. Current level of glycaemic control and its associated factors in patients with type 2 diabetes across Europe: data from the PANORAMA study. Clin Endocrinol (Oxf). 2014;80:47-56.

18. Stone MA, Charpentier G, Doggen K, Kuss O, Lindblad U, Kellner C, et al. Quality of care of people with type 2 diabetes in eight European countries: findings from the Guideline Adherence to Enhance Care (GUIDANCE) study. Diabetes Care. 2013;36:2628-38.
19. Széles G, Vokó Z, Jenei T, Kardos L, Pocsai Z, Bajtay $A$, et al. A preliminary evaluation of a health monitoring programme in Hungary. Eur J Public Health. 2005;15:26-32.

20. Nagy A, Adany R, Sandor J. Effect of diagnosis-time and initial treatment on the onset of type 2 diabetes mellitus complications: a population-based representative cross-sectional study in Hungary. Diabetes Res Clin Pract. 2011;94:e65-7.

21. Nagy A, Nagy B, Adany R, Sandor J. Determinants of low referral rates for ophthalmologic examination in people with type 2 diabetes in Hungary. Diabetes Res Clin Pract. 2013;102:e29-31.

22. Nagy A, Kovács N, Pálinkás A, Sipos V, Vincze F, Szőllősi G, et al. Exploring quality of care and social inequalities related to type 2 diabetes in Hungary: nationwide representative survey. Prim Care Diabetes. 2018;12:199-211.

23. Sándor J, Nagy A, Jenei T, Földvári A, Szabó E, Csenteri $\mathrm{O}$, et al. Influence of patient characteristics on preventive service delivery and general practitioners' preventive performance indicators: a study in patients with hypertension or diabetes mellitus from Hungary. Eur J Gen Pract. 2018;24:183-91.

24. Sándor J, Nagy A, Földvári A, Szabó E, Csenteri O, Vincze F, et al. Delivery of cardio-metabolic preventive services to Hungarian Roma of different socio-economic strata. Fam Pract. 2017;34:83-9.

25. Cunningham SG, Carinci F, Brillante M, Leese GP, McAlpine RR, Azzopardi J, et al. Core Standards of the EUBIROD Project. Defining a European Diabetes Data Dictionary for Clinical Audit and Healthcare Delivery. Methods Inf Med. 2016;55:166-76. 